UDC 616.31-02-07:616.379-008.64

S.A. Shnaider ${ }^{1}$,
V.Ya. Skyba ${ }^{1}$,
O.V. Skyba ${ }^{1}$,
H.O. Babenya ${ }^{1}$,
S.D. Varzhapetian ${ }^{2}$

https://doi.org/10.26641/2307-0404.2020.3.214854

\section{THE STATE OF ORAL MUCOSA IN PATIENTS WITH TYPE 2 DIABETES}

\author{
SE "Institute of Stomatology and Maxillofacial Surgery of National Academy of Medical Sciences of Ukraine" ${ }^{1}$ \\ Rishelievska st., 11, Odessa, 65026, Ukraine \\ SE "Zaporizhzhia Medical Academy of Postgraduate Education of Ministry of Health of Ukraine" 2 \\ Vintera boul. 20, Zaporizhzhia, 69096, Ukraine \\ ДУ «Інститут стоматології та щелепно-лицевої хірургї НАМН України» \\ вул. Рішельєвьска, 11, Одеса, 65026, Україна \\ ДУ «Запорізька медична академія післядипломної освіти МОЗ України» ${ }^{2}$ \\ бул. Вінтера, 20, Запоріжжя, 69096, Україна \\ e-mail: annababenya@gmail.com
}

\author{
Цитування: Медичні перспективи. 2020. Т. 25, № 3. С. 153-160 \\ Cited: Medicni perspektivi. 2020;25(3):153-160
}

Key words: diabetes mellitus, oral mucosa, generalized periodontitis, tooth decay

Ключові слова: иукровий діабет, слизова оболонка порожнини рота, генералізований пародонтит, карієс зубів

Ключевые слова: сахарный диабет, слизистая оболочка полости рта, генерализованный пародонтит, кариес зубов

\begin{abstract}
The state of oral mucosa in patients with type 2 diabetes. Shnaider S.A., Skyba V.Ya., Skyba O.V., Babenya H.O., Varzhapetian S.D. Aspects of the relationship between somatic and dental diseases are multifaceted. The bidirectional, mutually aggravating nature of the relationship between somatic and dental pathology is exemplified by diabetes mellitus. Numerous studies indicate that uncontrolled diabetes contributes to a multiple increase in the risk of caries and tooth loss, damage to the salivary glands, periodontium and oral mucosa. Given that diabetes affects all the main components of the etiology and pathogenesis of dental diseases, the urgent task of dentistry is to develop adequate methods for the treatment and prevention of dental pathology due to the presence of diabetes in the patient, which cannot be done without assessing the dental status of patients in this category. The purpose of the study was a comparative assessment of the state of oral tissues in patients with type 2 diabetes and in people of the similar age without somatic pathology. We examined 70 patients aged 34-48 years, of which 35 patients with type 2 diabetes and 35 healthy individuals of the similar age. Recruitment of patients with diabetes was carried out on the basis of the Communal non-profit enterprise "Odessa Regional Endocrinological Dispensary." All patients were clinically and radiologically examined. It was shown that the prevalence and intensity of the carious process in people with diabetes did not differ from the control group, however, the " $E$ " component prevailed in the structure of the DEF index, the need for prosthetics was $79.1 \%$. Hygiene was by $21.8 \%$ worse. All patients with diabetes were diagnosed with generalized periodontitis with the prevalence of an exacerbated course $(25.7 \%$ more) and a direct dependence of the severity of periodontitis from the degree of decompensation of diabetes. Periodontal indices in patients with diabetes were increased: PMA index - by 70.6\%, bleeding index - by 2 times, Russell index - by 1.9 times. In $63.6 \%$ of patients with diabetes, changes in the oral mucosa were noted. $25.7 \%$ of patients noted the development of candidal stomatitis/glossitis in the past. The functional activity of the salivary glands was reduced by $38.1 \%$. Microcrystallization of saliva in patients with diabetes is represented mainly by IV and V classes according to Leus-Kukina, which indicates its reduced mineralizing ability and the maximum risk of dental caries development.
\end{abstract}

Реферат. Состояние тканей полости рта у пациентов с сахарным диабетом 2 типа. Шнайдер С.А., Скиба В.Я., Скиба А.В., Бабеня А.А., Варжапетян С.Д. Аспекты взаимосвязи соматических и стоматологических заболеваний носят многогранный характер. Двунаправленный взаимоотягощающий характер взаимосвязи соматической и стоматологической патологии проявляется на примере сахарного диабета. Многочисленные исследования свидетельствуют о том, что неконтролируемый сахарный диабет способствует многократному увеличению риска развития кариеса и потери зубов, поражения слюнных желез, тканей пародонта, слизистой оболочки полости рта. Учитыввая то, что сахарный диабет затрагивает все основные составляющие этиологии и патогенеза стоматологических заболеваний, актуальной задачей 
стоматологии является разработка адекватных методов лечения и профилактики стоматологической патологии, обусловленной наличием у паџиента сахарного диабета, что невозможно сделать без оценки стоматологического статуса пациентов данной категории. Цель исследования - сравнительная оценка состояния тканей полости рта у больных сахарным диабетом 2 типа и у лии аналогичного возраста без соматической патологии. Обследовано 70 пациентов в возрасте 34-48 лет, из которых 35 больных сахарным диабетом 2 типа и 35 практически здоровых лии аналогичного возраста. Набор пациентов с сахарным диабетом проведен на базе Коммунального некоммерческого предприятия «Одесский областной эндокринологический диспансер». Все паџченты были клинически и рентгенологически обследованы. Показано, что распространенность и интенсивность кариозного процесса у лии с сахарным диабетом не отличалась от контрольной группы, однако в структуре индекса КПУ превалировал компонент «У» (на 40\% больще), нуждаемость в протезировании составила 79,1\%. Уровень гигиень был на 21,8\% хуже. Всем пациентам с сахарным диабетом был поставлен диагноз Генерализованный пародонтит с превалированием больных $c$ обострившимся течением (на 25,7\% больше) и прямой зависимостью степени тяжести пародонтита от степени декомпенсачии сахарного диабета. Пародонтальные индексы у пациентов с сахарным диабетом были повышены: индекс РМА - на 70,6\%, индекс кровоточивости - в 2 раза, индекс Рассела - в 1,9 раза. У 63,6\% больных сахарным диабетом отмечались изменения слизистой оболочки полости рта. У 25,7\% пациентов отмечалось развитие кандидозного стоматита/глоссита в прочлом. Функциональная активность слюнных желез была снижена на 38,1\%. Микрокристаллизация слюны у пациентов с сахарным диабетом представлена, в основном, IV и V классами по Леусу-Кукиной, что свидетельствует о пониженной ее минерализуюшей способности и максимальном риске развития кариеса зубов.

Aspects of the relationship between somatic and dental diseases are multifaceted due to the fact that almost all diseases of the internal organs to some extent are reflected in the oral cavity $[6,13]$.

A large group of diseases of the oral cavity are symptomatic stomatitis, periodontitis, caries which occur in disorders of the endocrine system and, above all, in diabetes [15].

Diabetes mellitus (DM) is a steadily progressing disease and is recognized worldwide as a noninfectious epidemic. According to the International Diabetes Federation (IDF), there are currently 382 million people with diabetes in the world, and by the year 2030 the total number of people with diabetes is supposed to reach 592 million [11].

Epidemiological studies of diabetes in Ukraine also show a steady increase in the number of patients in the population (by 5-7\% annually). In total, in 2017, there were 1.5 million patients with diabetes in Ukraine, more than 8.5 thousand of them are children. However, experts believe that in fact the prevalence of diabetes in our country is 2-2.5 times higher due to undiagnosed cases of the disease [10].

Type 2 diabetes is a heterogeneous and multifactorial disease. The disease develops in the system of metabolic syndrome and is the basis for the development of cardiovascular disease, lesions of the central nervous system, nephro- and rhinopathy $[1,12]$.

In type 2 diabetes insulin is produced in normal amounts or even in increased amounts but the mechanism of interaction of insulin with the cells of the body is disrupted (insulin resistance is formed). The main cause of insulin resistance is dysfunction of membrane receptors for insulin, and, above all, in obesity (the main risk factor, $80 \%$ of diabetics are overweight) - the receptors become unable to interact with the hormone due to changes in their structure or quantity [14].

Diabetes mellitus is a serious socio-medical problem due to its wide prevalence, constantly progressing nature of metabolic disorders, early development of vascular disorders, lesions of the oral mucosa, the presence of candidiasis [7, 9].

Hyperglycemia causes a double effect on the condition of the oral cavity: on the one hand, increasing level of glucose in the oral fluid promotes the reproduction of the microflora, on the other - the end products of glycolysis, formed in hyperglycemia, lead to increased mediators of inflammation [4].

Given that diabetes, in one way or another, affects all major components of the etiology and pathogenesis of dental diseases such as bacterial invasion, protective properties of the body and oral tissues, reparative properties of the latter, blood circulation and metabolism in them, the urgent task of dentistry is development of adequate methods of treatment and prevention of dental pathology caused by diabetes, which cannot be done without assessing the dental status of patients in this category.

The aim of the study was to study the condition of oral tissues in patients with type 2 diabetes mellitus in a comparative aspect with persons of similar age without somatic pathology.

\section{MATERIALS AND METHODS OF RESEARCH}

In clinical and laboratory studies 70 patients aged 34-48 years of which 35 patients with type 2 diabetes (main group) took part. Practically healthy 35 individuals of the same age were in the control group. The criteria for exclusion of patients from the 
control group were the presence of concomitant somatic pathology (especially in the stage of decompensation), long-term use of drugs, bad habits, etc.

Recruitment of patients was carried out on the basis of the Municipal Non-Profit Enterprise "Odesa Regional Endocrinology Dispensary" of the Odesa Regional Council. Clinical and laboratory examination of the dental status of patients was conducted on the basis of the State Establishment "Institute of Stomatology and Maxillofacial Surgery of National Academy of Medical Sciences of Ukraine" (Odessa).

Dental examination of patients to identify pathological changes began with the collection of anamnesis, assessment of the general condition of the body, a detailed clinical examination of the oral cavity. Visual examination of the oral cavity of patients determined the color of the mucous membrane, its moisture, the presence of plaque and elements of the lesion, edema, folding, consistency of saliva, quality of oral care was assessed.

The condition of the hard dental tissues was assessed by the DEF index (WHO). The state of oral hygiene was assessed using the Green-Vermilion indices taking into account the component of tartar, Silness-Loe and Stallard [8].

To assess the condition of periodontal tissues, PMA index (in\%), Schiller-Pisarev test, gum bleeding index (according to Müllemann-Cowell), Russell periodontal index (PI) were used, the depth of probing of periodontal pockets $(\mathrm{PC})$ was determined [ 8].
Orthopantomography (ORTHOPHOS XG 3, Sirona, Germany, X-ray tube characteristics $80 \mathrm{kV}$, $10 \mathrm{~mA}$ ) was performed to assess the degree and nature of bone destruction of alveolar processuses and to clarify the diagnosis.

Periodontal diagnosis was established according to the classification of periodontal diseases by Danilevsky NF [8].

To assess the functional state of the salivary glands, the rate of salivation by the method of Leontiev VK, Petrovich YuA. was evaluated [2]. The mineralizing function of saliva was determined by the method of Leus PA [5].

Statistical processing of the obtained results was performed by biostatistical methods of analysis on an IBM PC personal computer in the licensed software packages MS Excel 2010 and Statistica 6.1 (StatSoftInc., Serial N AGAR909E415822FA) in Windows XP mode. The arithmetic mean, standard deviation, reliability was calculated. When determining the degree of probability, accuracy $<0.05$, $\mathrm{P}=95.0 \%$ was accepted. Quantitative results in the samples were evaluated using Student's t-test for dispersed samples [3].

\section{RESULTS AND DISCUSSION}

The clinical examination of patients with diabetes revealed a high prevalence of dental caries, which was $94.8 \%$ and did not differ from the control group of practically healthy patients $(95.7 \%)$ (Table 1$)$.

Table 1

\section{The condition of hard dental tissues and periodontal tissues in patients with type 2 diabetes mellitus $(M \pm m)$}

\begin{tabular}{|c|c|c|c|c|c|c|}
\hline $\begin{array}{l}\text { Groups of } \\
\text { patients }\end{array}$ & $\begin{array}{c}\text { Prevalence of } \\
\text { dental caries, } \%\end{array}$ & $\begin{array}{l}\text { DEF, } \\
\text { points }\end{array}$ & PMA index, \% & $\begin{array}{c}\text { Bleeding index, } \\
\text { points }\end{array}$ & $\begin{array}{c}\text { PC depth, } \\
\text { mm }\end{array}$ & $\begin{array}{c}\text { Russel Index, } \\
\text { points }\end{array}$ \\
\hline $\begin{array}{l}\text { Control } \\
\text { group }\end{array}$ & 95.7 & $14.50 \pm 2.0$ & $37.64 \pm 8.5$ & $1.05 \pm 0.10$ & $0.82 \pm 0.09$ & $2.10 \pm 0.25$ \\
\hline $\begin{array}{l}\text { Main group } \\
\text { (type } 2 \text { diabetes) }\end{array}$ & 94.8 & $14.10 \pm 1.8$ & $\begin{array}{c}64.20 \pm 9.4 \\
p=0.039\end{array}$ & $\begin{array}{l}1.99 \pm 0.17 \\
p=0.00001\end{array}$ & $\begin{array}{c}4.93 \pm 0.6 \\
p=0.00001\end{array}$ & $\begin{array}{c}3.99 \pm 0.25 \\
p=0.001\end{array}$ \\
\hline
\end{tabular}

Note. $\mathrm{p}$ - probability index calculated in relation to the control group.

The degree of dental caries in patients with diabetes was distributed as follows: a high and very high degree prevailed ( $74.5 \%$ and $22.4 \%$, respectively), the average degree of damage was only $3.1 \%$.

As for the intensity of the carious process, it was also identical in the study groups $(14.5 \pm 2.0$ points in the control group, $14.1 \pm 1.8$ points in people with diabetes), but the ratio of the components "decay", "extracted", "filled"teeth in the total DEF index were different. Thus, in the main group, component $\mathrm{D}$ was $14.3 \%$, component $\mathrm{F}$ was $34.3 \%$, and component $\mathrm{E}$ was $51.4 \%$. In the comparison group, component D was $31.5 \%$, component $\mathrm{F}$ was $57.1 \%$ and component E was $11.4 \%$. The obtained data indicate that in patients with diabetes in the structure of the DEF index, component $\mathrm{E}$ predominates, which indicates a large number of missing teeth (Fig. 1). 


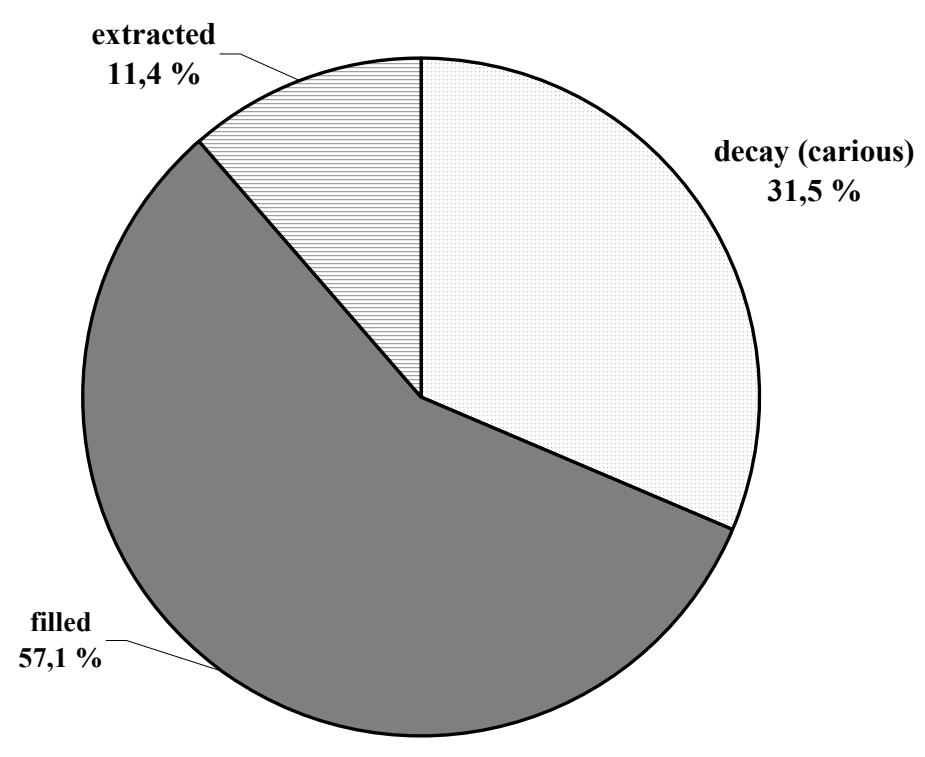

Control group

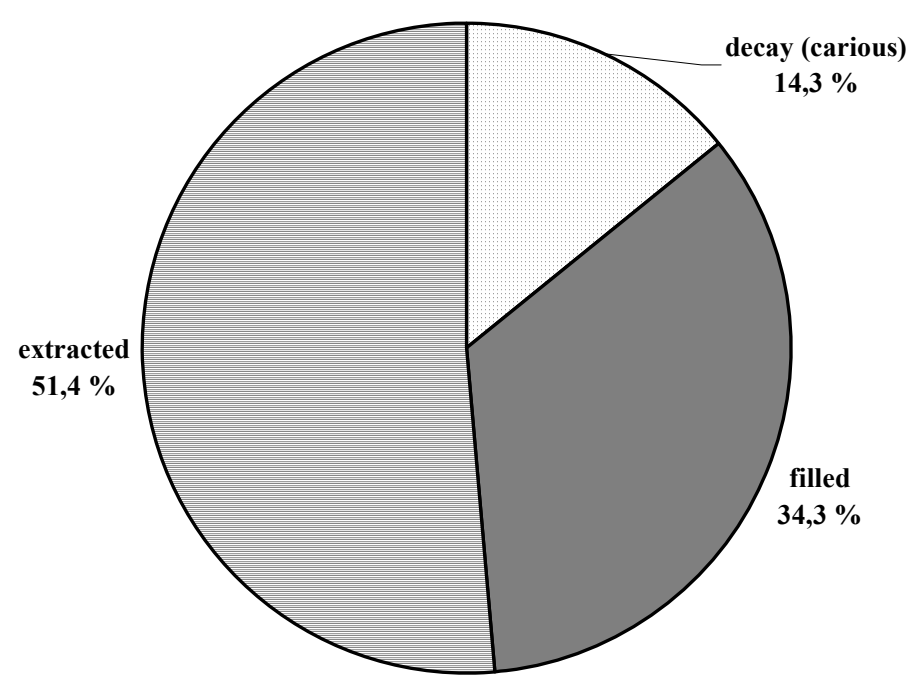

Main group (DM)

Fig. 1. Structure of the DEF index in patients of different observation groups

As a result of secondary adentia in people with diabetes, their high need for prosthetics and tooth restoration attracts attention. The need for prosthetics was $79.1 \%$ : in non-removable prosthetics $-26.8 \%$, in removable $-24.7 \%$, in removable and non-removable $-23.71 \%$.

Determining oral hygiene state in diabetes patients, an insufficient level of oral care was revealed. Thus, satisfactory and good hygiene was in $52.5 \%$ of patients (which was by $21.8 \%$ less than in the control group with the same level of hygiene), in
$43.9 \%$ of patients oral hygiene corresponded to the indicators of unsatisfactory and poor (by $18.2 \%$ more than in the control group) (Table 2).

According to the results of clinical and radiological study of periodontal tissues, all $100 \%$ of patients with diabetes were diagnosed with generalized periodontitis (GP): $57.1 \%$ of patients were diagnosed with initial - I degree of GP, $32.5 \%$ of patients - I-II degree of GP, in 10.4\% - II-III degree of GP severity. 
State of oral hygiene in patients with type 2 diabetes mellitus

\begin{tabular}{|c|c|c|c|c|c|c|}
\hline \multirow{2}{*}{$\begin{array}{l}\text { Groups of } \\
\text { patients }\end{array}$} & \multicolumn{4}{|c|}{ Level of oral hygiene, $\%$} & \multicolumn{2}{|c|}{$\begin{array}{l}\text { Hygiene indices } \\
(M \pm \mathbf{m})\end{array}$} \\
\hline & $\begin{array}{c}\text { good } \\
(0-0.6 \text { points })\end{array}$ & $\begin{array}{c}\text { satisfactory } \\
(0.7-1.6 \text { points })\end{array}$ & $\begin{array}{c}\text { unsatisfactory } \\
\text { (1.7-2.5 points) }\end{array}$ & $\begin{array}{c}\text { poor } \\
(2.6 \text { or more points) }\end{array}$ & $\begin{array}{c}\text { Silness-Loe, } \\
\text { points }\end{array}$ & $\begin{array}{c}\text { Stallard, } \\
\text { points }\end{array}$ \\
\hline $\begin{array}{l}\text { Control } \\
\text { group }\end{array}$ & 25.7 & 48.6 & 22.9 & 2.8 & $0.93 \pm 0.08$ & $0.98 \pm 0.10$ \\
\hline $\begin{array}{l}\text { Main group } \\
\text { (type } 2 \\
\text { diabetes) }\end{array}$ & 20.0 & 32.5 & 32.5 & 11.4 & $\begin{array}{l}1.86 \pm 0.30 \\
p=0.0038\end{array}$ & $\begin{array}{c}1.82 \pm 0.40 \\
p=0.04\end{array}$ \\
\hline
\end{tabular}

Note. $\mathrm{p}$ - probability index calculated in relation to the control group.

In the control group, the structure of periodontal disease was as follows: chronic catarrhal gingivitis was diagnosed in $45.7 \%$ of patients, primary I degree of GP - in $28.6 \%$ of subjects, I, I-II degree of $\mathrm{GP}-$ in $25.7 \%$ of people.

With regard to GP course, in the main group exacerbations of GP were diagnosed in $45.7 \%$ of people, in the control group periodontal diseases in the exacerbation stage were in $20.0 \%$ of patients.

There was a direct dependence of the severity of GP on the degree of decompensation of diabetes. When examining patients with compensated and subcompensated diabetes, the number of people with GP of III severity was $5.7 \%$, among patients with decompensated diabetes $-19.8 \%$ (Fig. 2).

When collecting the anamnesis, patients noted bleeding gums during brushing for many years, as well as fetor oris, rapid plaque formation, swelling, bright red color of the gingival margin, tartar deposits, pain in the gums.

The index assessment of the condition of periodontal tissues in people with diabetes revealed high values of the PMA index (64.2 $\pm 9.4 \%)$, which indicates a severe degree of symptomatic gingivitis $(\mathrm{p}=0.039)$.

The bleeding index in patients with diabetes was by 1.89 times higher than in patients without somatic pathology $(p=0.00001)$. The index of PI (Russel) $(3.99 \pm 0.25$ points, $\mathrm{p}=0.001)$ indicated a moderate and severe degree of GP in patients of the main group.

Along with periodontal pathology in $63.6 \%$ of diabetes patients there were changes in the oral mucosa - edema, punctate hemorrhages on the palatine arches and the inner surface of the lower lip, dryness and atrophy of the papillae of the tongue, erosion of the cheek mucosa. $25.7 \%$ of patients with diabetes had a history of candidal stomatitis/glossitis.
One of the earliest and most frequent manifestations of diabetes is an impairment of the secretory function of the salivary glands, which leads to xerostomia, accompanied by complaints of dry mouth.

When studying the functional activity of the salivary glands in all examined patients with diabetes, hyposalivation associated with structural and functional changes in the vessels of the salivary glands was found. Patients reported dry mouth. On examination, viscosity and a small amount of oral fluid were noted. The salivation rate in the main group was $0.39 \pm 0.02 \mathrm{ml} / \mathrm{min}$, in the control group $0.63 \pm 0.04 \mathrm{ml} / \mathrm{min}$, which was by $38.1 \%$ more $(\mathrm{p}=0.0001)$.

Microcrystallization of saliva in patients with diabetes is represented mainly by IV and V classes according to Leus-Kukina, this indicates its reduced mineralizing ability and the maximum risk of dental caries.

Thus, the results of a comparative assessment of the dental status of patients with diabetes and people of similar age without somatic pathology found that hyperglycemia leads to a more severe course of periodontal disease, reduces the functional activity of the salivary glands, which coincides with the data obtained by Kilmukhametova Yu.H. et al. [13], Sadeghi R. et al. [15]. As for the indicators of the carious process, its prevalence and intensity were almost the same in the comparison group and in people with diabetes, which coincides with the data of Sadeghi R. et al. [15], however, the established fact of the prevalence of extracted teeth over decay and filled ones in people with diabetes attracts the attention.

When prescribing treatment and means of preventing dental pathology to patients with diabetes mellitus, one should take into account the identified disorders in the tissues of the oral cavity and the 
pathogenesis of their development, this is directly related to the presence of somatic pathology, namely diabetes, and planning dental treatment to diabetes patients is recommended only after consulting with an endocrinologist.
The results of the study can serve as a theoretical and methodological basis for the search and development of multifunctional correctors and schemes for the prevention and treatment of dental pathology in patients with diabetes.

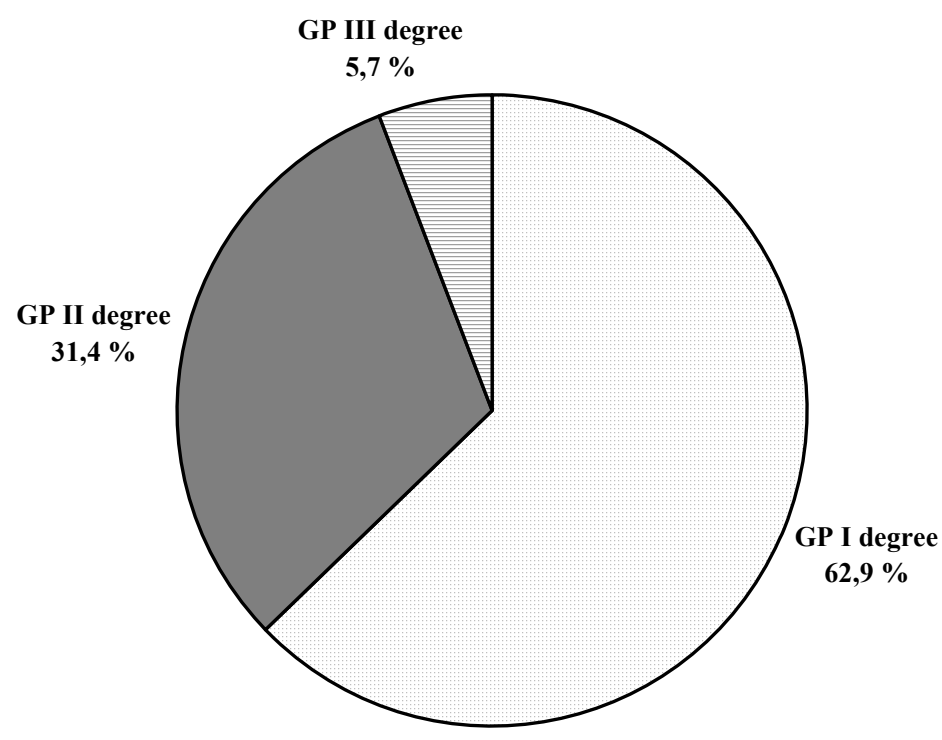

Patients with compensated or subcompensted DM

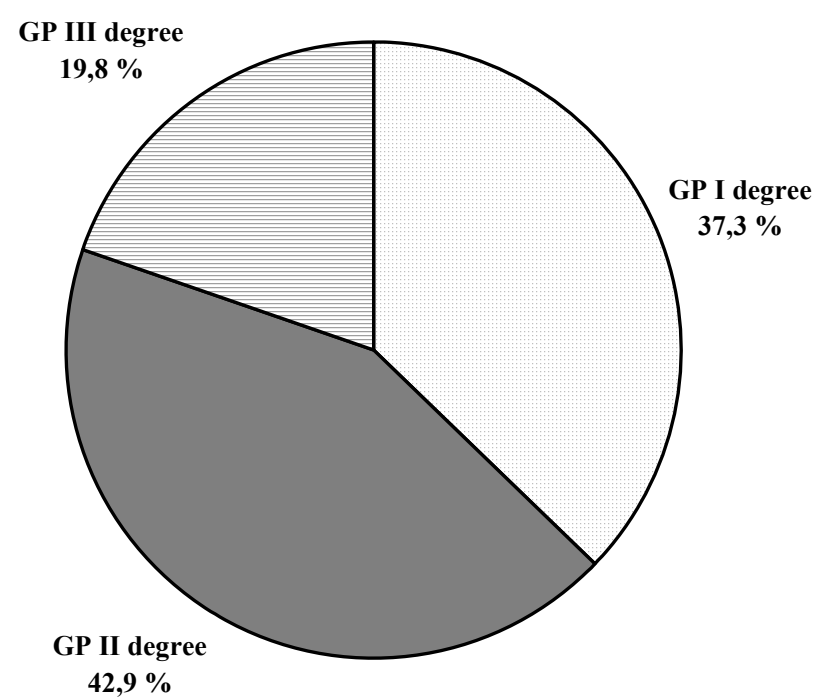

Patients with decompensated DM

Fig. 2. Structure of periodontal diseases in patients with DM depending on DM compensation degree 


\section{CONCLUSIONS}

1. The presence of type 2 diabetes mellitus in a patient is a risk of developing or aggravating inflammatory-dystrophic periodontal diseases.

2. The severity of generalized periodontitis in patients with diabetes directly depends on the degree of compensation of somatic disease.

3. Clinical and laboratory examinations of patients with diabetes indicate that patients in this group need not only regular medical examination and prevention of dental complications of diabetes in the oral cavity, but also constant therapeutic and orthopedic treatment of dental pathology.
4. Detected disorders of salivary glands, salivary mineralizing function, poor oral hygiene and more aggressive course of inflammatory-dystrophic periodontal disease may form the basis for the development of new methods of treatment and prevention of dental diseases.

5. If patients are diagnosed with generalized periodontitis of II-III degree of severity with severe hyposalivation, it is recommended to consult an endocrinologist with a study of blood sugar index.

Conflict of interest. The authors declare no conflict of interest.

\section{REFERENCES}

1. Volkova EA, Malygina OF. [Diabetes mellitus and cardiovascular diseases. Actual approach to lifestyle modification and treatment of patients with type 2 diabetes]. Consilium Medicum. 2019;21(1):74-80. Russian. doi: https://doi.org/10.26442/20751753.2019.1.190273

2. Leontev VK, Kiselnikova LP. [Pediatric Therapeutic Dentistry: National Guide]. Moskva: GEOTARMedia; 2017. p. 952. Russian.

3. Zubov NN, Kuvakin VI, editors. [Methods of multivariate statistical data analysis in medicine: a training manual]. Sankt-Peterburg: OOO "Litografiya Print"; 2017. p. 348. Russian.

4. Klenovska SV. [Comparative aspects of candidiasis in patients with diabetes mellitus]. East European Science Journal. 2018;9(37 part 2):22-26. Ukrainian.

5. Leus PA. [Dental health indicators. What they point to?]. Sovremennaya stomatologiya. 2015;1:4-7. Russian.

6. Naumova VN, Turkina SV, Maslak EE. [The relationship of dental and somatic diseases]. Volgogradskiy nauchno-medicinskiy zhurnal. 2016;2:25-28. Russian.

7. Nemtsova VD. [Diabetes mellitus and sudden death: resolved and unresolved issues]. Svit medytsyny ta biologii. 2015;2(50):206-211. Russian.

8. Danylevskyi NF, et al. [Therapeutic dentistry: in 4 volumes - Vol. 3. Periodontal disease: a textbook]. Borysenko AV, editor. Kyiv: Medytsyna; 2018. p. 624 Ukrainian.
9. Tsytovskyi MN. [Statistical, clinical and morphological aspects of the flow of cerebral diabetes to the camp of the heart-ship system]. Naukovyi visnyk Uzhgorodskogo universytetu: Medycyna. 2017:1(55):168-77. Ukrainian.

10. [Resolution of the round table meeting of the Health Committee of the Verkhovna Rada of Ukraine "Diabetes. International experience. Problems and opportunities in Ukraine"]. Kyiv; (2018). Ukrainian. Available from: http://komzdrav.rada.gov.ua/uploads/documents/30887.pdf

11. American Diabetes Association. Diabetes Care. 2015;38(1):1-594.

12. Global report on diabetes, WHO, 2018:84. Available from:

https://apps.who.int/iris/bitstream/handle/10665/204871/9 789241565257_eng.pdf? sequence=1

13. Kilmukhametova YuH, Batig VM, Basista AS. Periodontal diseases on the background of various somatic pathologies. Deutscher Wissenschaftsherold. 2018;3:26-29. doi: https://doi.org/10.19221/201838

14. Mehmet E Okur, Ioannis D Karantas, Panoraia I Siafaka. Diabetes Mellitus: A Review on Pathophysiology, Current Status of Oral Medications and Future Perspectives. Acta Pharm. Sci. 2017;55(1). doi: https://doi.org/10.23893/1307-2080.APS.0555

15. Sadeghi R, Taleghani F, Mohammadi S, Zohri Z. The effect of diabetes mellitus type $\mathrm{i}$ on periodontal and dental status. J Clin Diagn Res. 2017 Jul;11(7):ZC14-7. doi: https://doi.org/10.7860/JCDR/2017/25742.10153

\section{СПИСОК ЛІТЕРАТУРИ}

1. Волкова Е. А., Малыгина О. Ф. Сахарный диабет и сердечно-сосудистые заболевания. Актуальный подход к модификации образа жизни и лечению пациентов с сахарным диабетом 2-го типа. Consilium Medicum. 2019. T. 21, № 1. C. 74-80. DOI: https://doi.org/10.26442/20751753.2019.1.190273

2. Детская терапевтическая стоматология: национальное руководство / под ред. В. К. Леонтьева, Л. П. Кисельниковой. Москва: ГЭОТАР-Медиа, 2017. 952 с.
3. Зубов Н. Н., К Кувакин В. И. Методы многомерного статистического анализа данных в медицине: учеб. пособие / под ред. доц. Н. Н. Зубова. СанктПетербург: ООО "Литография Принт", 2017. 348 с.

4. Кленовська С. В. Порівняльні аспекти перебігу кандидозного стоматиту у пацієнтів, хворих на цукровий діабет. East European Science Journal. 2018. Vol. 37, No. 9, part 2. P. 22-26. 
5. Леус П. А. Индикаторы стоматологического здоровья. На что они указывают? Совр. стоматология. 2015. № 1. С. 4-7.

6. Наумова В. Н., Туркина С. В., Маслак Е. Е. Взаимосвязь стоматологических и соматических заболеваний. Волгоград. научно-мед. журнал. 2016. № 2. С. 25-28.

7. Немцова В. Д. Сахарный диабет и внезапная смерть: решенные и нерешенные вопросы. Світ медицини та біологіï. 2015. Т. 50, № 2. С. 206-211.

8. Терапевтична стоматологія: у 4 т. Том 3. Захворювання пародонта: підручник / М.Ф. Данилевський та ін.; ред. А. В. Борисенко. Київ: Медицина, 2018. $624 \mathrm{c}$.

9. Цитовський М. Н. Статистичний, клінічний та морфологічний аспекти впливу цукрового діабету на стан серцево-судинної системи. Наук. вісник Ужгород. університету. (Серія «Медицина»). 2017. Т. 55, Вип. 1. С. 168-177.

10. Цукровий діабет. Міжнародний досвід. Проблеми та можливості в Україні: Резолюція засідання «круглого столу» Комітету з питань охорони здоров'я Верховної ради України. Київ, 2018. URL://komzdrav.rada.gov.ua/uploads/documents/30887.pdf

11. American Diabetes Association. Diabetes Care. 2015. Vol. 38, No. 1. P. S1-594.

12. Global report on diabetes / WHO, 2018. $84 \mathrm{p}$. URL: https://apps.who.int/iris/bitstream/handle/10665/20 4871/9789241565257_eng.pdf?sequence=1

13. Kilmukhametova Yu. H., Batig V. M., Basista A. S. Periodontal diseases on the background of various somatic pathologies. Deutscher Wissenschaftsherold. 2018. No. 3. P. 26-29. DOI: https://doi.org/10.19221/201838

14. Mehmet E. Okur, Ioannis D. Karantas, Panoraia I. Siafaka. Diabetes Mellitus: a Review on Pathophysiology, Current Status of Oral Medications and Future Perspectives. Acta Pharm. Sci. 2017. Vol. 55, No. 1. DOI: https://doi.org/10.23893/1307-2080.APS.0555

15. Sadeghi R., Taleghani F., Mohammadi S., Zohri Z. The effect of diabetes mellitus type i on periodontal and dental status. J. Clin Diagn Res. 2017 Jul. (Vol. 11, No. 7). P. ZC14-ZC17.

DOI: https://doi.org/10.7860/JCDR/2017/25742.10153

The article was received 2019.11 .25 
